\begin{tabular}{c|c|c|c|c|c|c|c|} 
DOI: http://dx.doi.org/10.21276/ap.covid19.2021.10.1.10 \\
Annals of Phytomedicine: An International Journal \\
http://www.ukaazpublications.com/publications/index.php \\
Print ISSN : 2278-9839
\end{tabular}

\title{
Aspects of plant biotechnology in combating COVID-19 infection
}

\author{
Alka Rani and Wamik Azmi \\ Department of Biotechnology, Himachal Pradesh University, Summerhill, Shimla-171005, Himachal Pradesh, India
}

\begin{tabular}{|c|c|}
\hline Article Info & Abstract \\
\hline $\begin{array}{l}\text { Article history } \\
\text { Received } 13 \text { March } 2021 \\
\text { Revised } 30 \text { April } 2021 \\
\text { Accepted } 30 \text { April } 2021 \\
\text { Published Online } 30 \text { June } 2021\end{array}$ & $\begin{array}{l}\text { The novel COVID-19 disease pandemic is still at its height caused by severe acute respiratory syndrome- } \\
2 \text { (SARS-CoV-2), causing thousand of death every week. It has extremely high infectivity, a short } \\
\text { doubling time and a high risk of nosocomial infection. COVID-19 is a sudden disaster which has not been } \\
\text { previously identified in humans and resulted in a public crisis. However, prevention and management } \\
\text { are the best options. Several efforts are made by the researchers to develop vaccines, therapeutic and }\end{array}$ \\
\hline $\begin{array}{l}\text { Keywords } \\
\text { COVID-19 } \\
\text { SARS-CoV-2 } \\
\text { Plant biotechnology } \\
\text { Plant molecular farming } \\
\text { Recombinant proteins }\end{array}$ & $\begin{array}{l}\text { antiviral drugs to curb the spread of COVID-19 disease. Plant biotechnology is used for the development } \\
\text { of test kit reagents, vaccines, immunomodulatory proteins, monoclonal antibodies and antiviral drugs. } \\
\text { The rapid production of biologicals on an industrial scale could be facilitated by plant molecular } \\
\text { farming (PMF). In the present scenario of the COVID-19 pandemic, PMF has the potential to fulfill } \\
\text { emergency demands. Therefore, this is the most attractive approach in terms of cost, scalability, } \\
\text { safety, easy delivery and mucosal immunity induction. }\end{array}$ \\
\hline
\end{tabular}

\section{Introduction}

Coronovirus (CoVs) is a single stranded RNA virus which causes respiratory, gasterointestinal, hepatic and neurological diseases in humans and animals (Weiss and Leibowitz, 2011). The first case of the novel coronavirus was reported on December 30, 2019, in the city of Wuhan, Hubei province, China (Xu et al., 2020). On March 11 th, the WHO formally announced that COVID-19 was a pandemic disease. COVID-19 was confirmed to have reached India on January 27, 2020, when the first COVID-19 case confirmed in Kerala was a 20 yr old female returned from Wuhan city, China, on January 23, 2020.

With the world's population at over 6.4 billion, majority of the poor people need affordable technological solutions to health. Protection from viral infections is currently the most difficult area to deal through drug development. Progress in plant genetic engineering has opened novel opportunities to use plants as bioreactors for safe and price effective production of vaccine antigens. The use of plant-based technology has great potential for the production of many recombinant proteins. The developments in this area have significantly increased its utility and enabled various groups to explore the possibility of producing vaccine antigens from a variety of plants. Medicinal plants continue to be used in cities and rural communities as part of healthcare, because of their low cost and the easy access to plant products in all markets across the country (Akbli et al., 2016).

\section{Coronavirus}

Severe acute respiratory syndrome coronavirus 2 (SARS-CoV-2) is a newly emerged virus responsible for the pandemic which cause

Corresponding author: Dr. Wamik Azmi

Professor, Department of Biotechnology, Himachal Pradesh University, Summerhill, Shimla-171005,Himachal Pradesh, India E-mail: wamikazmi@rediffmail.com

Tel.: +91-9418311183

Copyright () 2021 Ukaaz Publications. All rights reserved.

Email: ukaaz@yahoo.com; Website: www.ukaazpublications.com worst socioeconomic disruption. The WHO named the disease as COVID-19 and it spread all over the world rapidly less than 3 months. SARS-CoV-2 has killed many people all over the countries and has presented a major threat to public health worldwide. The zoonotic transmission was considered as prime reason for appearance of this novel coronavirus in Wuhan city of China in December 2019 (Mackenzie and Smith, 2020). SARS-CoV-2 is an enveloped single stranded RNA ( + ) belongs to $\beta$ coronavirus of Coronaviridae family and Nidovirales order having symmetrical helical nucleocapsid (Table 1) (Khan et al., 2020).

COVID-19 disease with a high rate of transmission and highly nonspecific symptoms is an infectious disease caused by a newly discovered coronavirus. It is closely related to the viruses causing the earlier SARS (Severe Acute Respiratory Syndrome) and MERS (Middle East Respiratory Syndrome) outbreaks (Amanat and Krammer, 2020). More than 8000 infected cases by SARS-CoV and more than 774 deaths in 37 countries were confirmed during 200203 and MERS-CoV outbreak in September 2012, caused 2494 confirmed cases of infection and 858 mortalities, including 38 fatalities in South Korea (Lee et al., 2016; Lee et al., 2017). The large-scale epidemics have been caused by Middle East Respiratory Syndrome (MERS) and Severe Acute Respiratory Syndrome (SARS) but the transmission rate for COVID-19 is much higher (Gates, 2020). The coronavirus virion is typically round or multishaped. It has a diameter of 120-160 nm and includes a petal shaped projections consisting of a triple spikes protein, which is a common feature of the coronavirus. For some CoVs, the spikes on the surface are not only formed by trimers of $\mathrm{S}$ protein, but also HE (hemagglutinin-esterase) proteins. In particular, more than $11.1 \mathrm{M}$ peoples in the India are infected, resulting in $157 \mathrm{~K}$ deaths till $1^{\text {st }}$ March 2021. The disease symptoms are fever, cough, sore throat, runny nose and difficulty in breathing (Table. 2). Since the emergence of the virus, SARS-CoV-2 has affected more than $114 \mathrm{M}$ people with more than $2.53 \mathrm{M}$ deaths worldwide as of $1^{\text {st }}$ March 2021 
(Figure 1). At present, available data shows that SARS-CoV-2 spread the infection to the human population from a bat source. It is

Table 1: Classification of coronaviruses into four genera unknown if other animal species are related with this virus and acting as a host between humans and bat or not.

\begin{tabular}{|l|l|l|l|}
\hline \multicolumn{4}{|c|}{ Coronavirus } \\
\hline \multicolumn{1}{|c|}{ Alphacoronavirus } & \multicolumn{1}{|c|}{ Betacoronavirus } & Gammacoronavirus & \multicolumn{1}{c|}{ Deltacoronavirus } \\
\hline Infect mammals & Infect mammals & Infect avian species & $\begin{array}{l}\text { Infect both mammalian and } \\
\text { avian species. }\end{array}$ \\
\hline $\begin{array}{l}\text { Include human coronavirus } \\
\text { th63 (HCoV-NL63), porcine } \\
\text { transmissible gastroenteritis } \\
\text { coronavirus (TGEV), PEDV } \\
\text { coronavirus (PRCV). }\end{array}$ & $\begin{array}{l}\text { Include SARS-CoV, MERS-CoV, } \\
\text { bat coronavirus HKU4, mouse } \\
\text { hepatitis coronavirus (MHV), } \\
\text { bovine coronavirus (BCoV), } \\
\text { and human coronavirus OC43. }\end{array}$ & $\begin{array}{l}\text { Include avian infectious } \\
\text { bronchitis coronavirus } \\
\text { (IBV). }\end{array}$ & $\begin{array}{l}\text { Include Porcine deltacoronavirus } \\
\text { (PdCV). }\end{array}$ \\
\hline
\end{tabular}
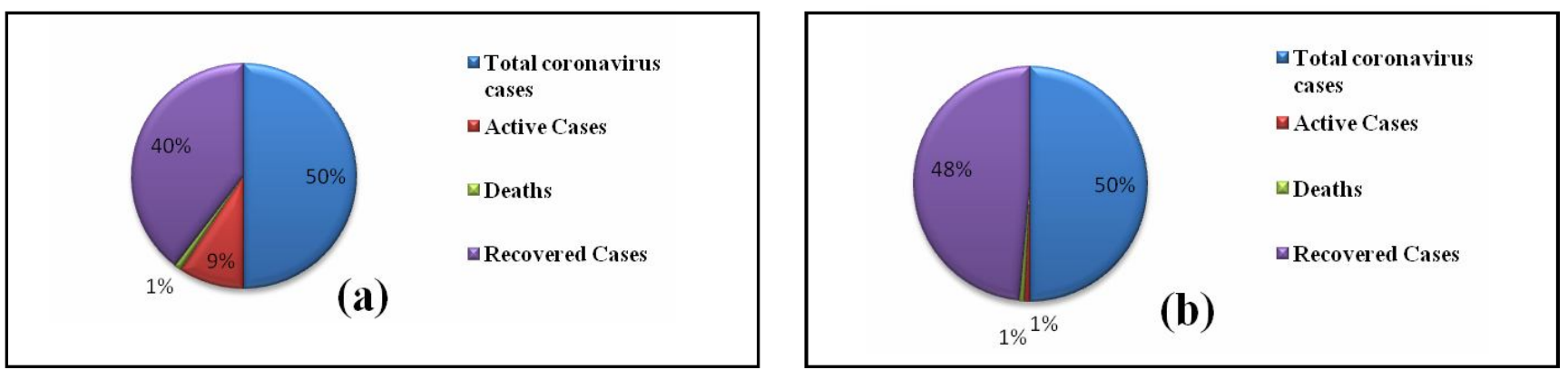

Figure 1: Global statistics of coronavirus pandemic (a) Statistics of India (b) till $1^{\text {st }}$ March, 2021.

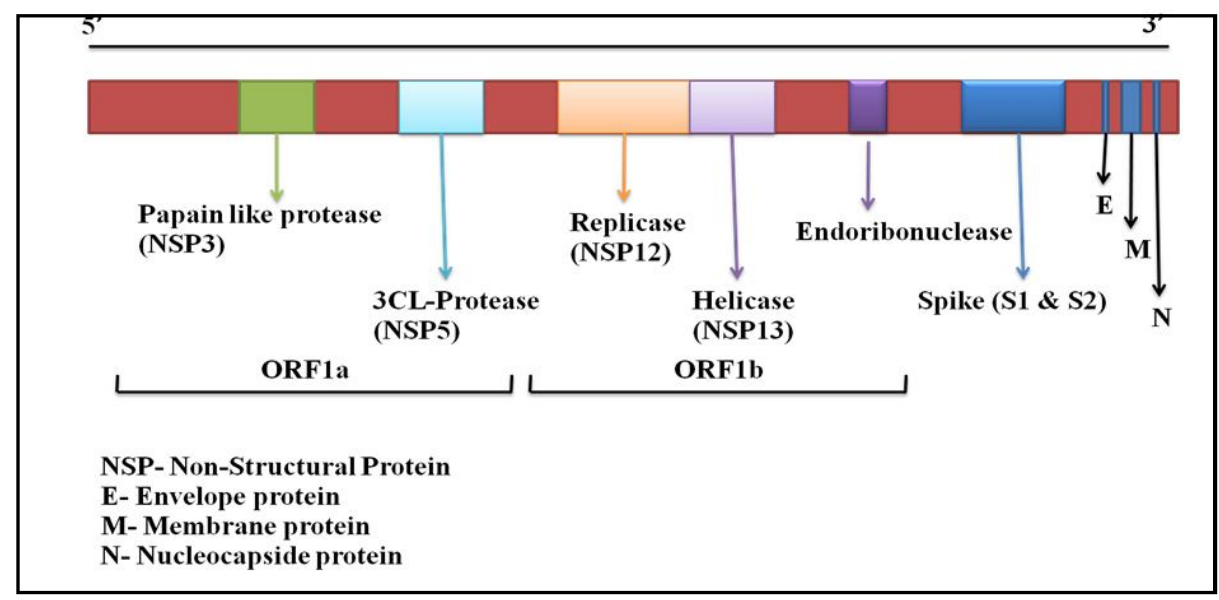

Figure 2: Single stranded RNA genome of SARS-CoV-2.

Table 2: Clinical conditions of COVID-19 infection

\begin{tabular}{|l|l|}
\hline S. No. & \multicolumn{1}{|c|}{ Conditions } \\
\hline 1 & Mild (uncomplicated) illness \\
2 & Moderate pneumonia \\
3 & Severe pneumonia \\
4 & Acute respiratory distress syndrome (ARDS) \\
5 & Extrapulmonary manifestations and systemic \\
& Complications \\
6 & Sepsis \\
7 & Septic shock \\
\hline
\end{tabular}

\subsection{COVID genome}

Full-genome sequencing of SARS-CoV-2 shows (Figure 2) that this virus is genetically similar to bat-SL-CoVZC45 and SARS-like betacoronavirus of bat origin, bat-SL-CoVZXC21 (accession number MG772934) (Lu et al., 2020). The SARS-CoV-2 strains are less similar to SARS-CoV and MERS-CoV genetically (about 79 and $52 \%$, respectively). The sequencing results of samples procured from Wuhan, China indicated that this virus comes from the subgenus Sarbecovirus. It is more analogous to bat-SL-CoVZC45 and bat-SLCoVZXC21 and both are bat-derived coronavirus strains than to other recognized human infecting coronaviruses, caused the SARS outbreak of 2003 (Piepenburg et al., 2006). 


\subsection{Mechanism of internalization of SARS-CoV-2}

The virus encodes 20 different proteins which includes four structural protein (Table. 3) (S-spike; E-envelope; M-membrane; $\mathrm{N}$-nucleocapsid) and many non structural proteins (such as RNA dependent RNA polymerase, coronavirus main protease and papain like protease) (Chen et al., 2020). The crown like appearance on coronoviruses is due to the spike protein which forms large protrusions from the virus surface. The enzyme responsible for the attachment of SARS-CoV-2 to human and bat cell and in its replication is angiotensin converting enzyme II (ACE2) (Walls et al., 2020; Zhou et al., 2020). A transmembrane protein (S protein) mediates the initiation of $\mathrm{CoV}$ infection by attaching to the specific receptors on the target cells. SARS-CoV-2 binds the host cells through interaction between the receptor binding motif of the spike proteinrecepter binding domain and ACE2 receptor. The changes in the conformation of C-terminal S2 subunit (responsible for virus- cell membrane fusion) of the spike protein occur due to this interaction. The formed complex of S protein -ACE2 is proteolytically cleaved by host cell - type 2II transmembrane seine protease TMPRSS2. The cleavage of ACE2 then leads to the entry of virus into host cell (Jiang et al., 2020; Rabi et al., 2020).

Table 3: Structural protein of virus and their function

\begin{tabular}{|l|l|l|}
\hline $\begin{array}{l}\text { SI. } \\
\text { No. }\end{array}$ & Protein & \multicolumn{1}{|c|}{ Function } \\
\hline 1. & S protein & $\begin{array}{l}\text { Mediate virus attachment and } \\
\text { membrane fusion }\end{array}$ \\
\hline 2. & E protein & Invoved in promoting virulence $(74-109$ aa) \\
\hline 3. & M protein & $\begin{array}{l}\text { Has N-terminus modified by an O-or- N-glycan } \\
\text { and a hydrophilic C-terminal tail (218-263 aa) }\end{array}$ \\
\hline 4. & N protein & $\begin{array}{l}\text { RNA bound phosphorylated protein that } \\
\text { facilitates appropriate folding of genomic } \\
\text { RNA into nucleocapsid (349-470 aa) }\end{array}$ \\
\hline
\end{tabular}

\section{Diagnostic tests for COVID-19}

The quick and early diagnosis of COVID-19 among population is the main prerequisite for timely treatment and control. Basically, molecular tests are used for confirmation of COVID-19, but serological tests are widely available and play an important role in understanding the epidemiology of the virus and in identifying populations at higher risk for infection. Some methods detect the presence of the virus itself through RT-PCR and isothermal nucleic acid amplification, while other tests detect antibodies produced as a reaction to the infection (Figure 3) (Abbasi and Jennifer, 2020).

\subsection{Direct tests}

\subsubsection{RT-PCR}

Currently, the preferred SARS-CoV-2 test is DNA amplification by PCR (Polymerase Chain Reaction) and the real-time versions of such tests were among the earliest available. RT-PCR based tests were already developed for SARS-CoV and Middle East respiratory syndrome coronavirus (MERS-CoV). Therefore, a testing approach based on PCR for SARS-CoV-2 diagnosis was an obvious choice (Johani and Hajeer, 2016). Real-time RT-PCR technology is the most used SARS-CoV-2 RNA detection (WHO, 2020).

\subsubsection{RT-LAMP (Reverse-Transcription-Loop-Mediated Isothermal Amplification)}

Recently, loop-mediated isothermal amplification (LAMP) method has been used for the rapid detection of virus-specific genes. This method includes an exponential amplification of specific nucleic acid sequences at a constant temperature. The specificity and sensitivity of this technique is comparable to that reported for RTPCR method. A combination of LAMP with reverse transcription (RT-LAMP) allows the direct detection of RNA, including SARSCoV-2 RNA (Huang et al., 2020).

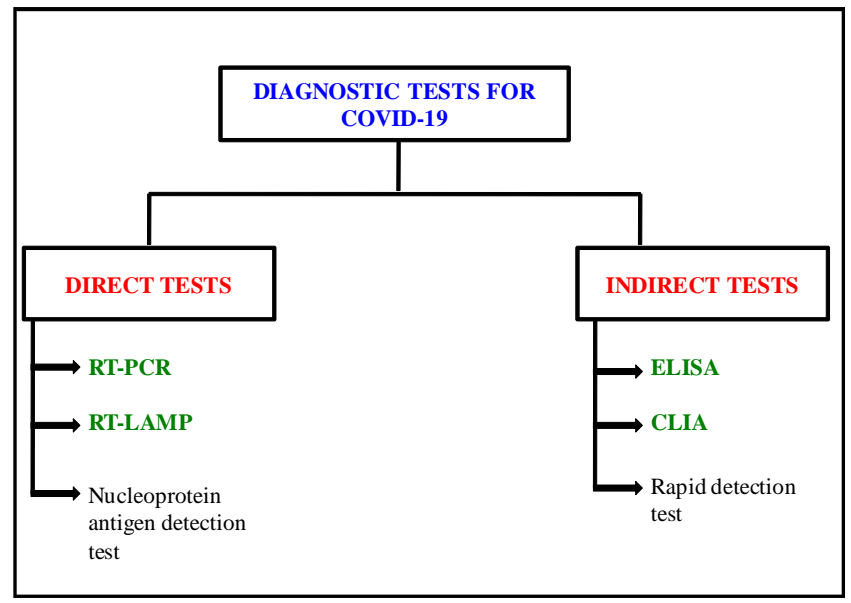

Figure 3: Diagnostic test for COVID-19.

\subsubsection{Nucleoprotein (NP) antigen detection test}

A double antibody sandwich ELISA identifies the SARS-CoV-2 nucleoprotein in a microtitre plate pre-coated with specific antibodies against SARS-CoV-2 nucleoprotein in combination with horseradish peroxidase-labeled secondary antibody against the same protein. This direct method is simple, rapid and does not require trained personnel and expensive laboratory instruments. However, in a meta-analysis by Castro et al. (2020) the sensitivity of this test ranged from $70-86 \%$, while the specificity ranged from $95-97 \%$, and thus a single negative test result cannot rule out SARSCoV-2 infection.

\subsection{Indirect tests}

The indirect diagnosis of SARS-CoV-2 infection is based on the detection of specific IgG and / or IgM antibodies. A more traditional test for virus infection is the presence of antibodies that bind to the virus. These tests can also identify the individuals who are healthy at present but may have previously been infected. This test is much more rapid than the nucleotide sequencing tests and only a small drop of blood is required. WHO also highlighted the strong need for rapid and inexpensive serological IgM and IgG tests (Cheng et al., 2020; Yang et al., 2020). Several such immunoassays have been developed for the detection of viral proteins and antibodies in serum or plasma samples of SARS-CoV-2 infected persons. The most extensively used commercial tests are based on enzyme linked immune assay (ELISA), automated chemiluminescence immunoassay (CLIA) and rapid lateral flow immunoassay (LFIA) (Vashist, 2020). 


\subsubsection{Enzyme-Linked immune assay (ELISA)}

The anti-SARS-CoV-2 IgG and IgM responses by identifying antibodies against the nucleoprotein and spike proteins have been detected by ELISA. The only limitation of this test is the lack of defined standards (Castro et al., 2020).

\subsubsection{Chemiluminescent immunoassay (CLIA)}

Light-producing chemical reactions (a substrate reacts with the Avidin-Horseradish Peroxidase resulting in light development) allowed estimating the titers of $\operatorname{IgG}$ and $\operatorname{IgM}$ by the amount of the emitted luminous signal. A better quantification of antibodies can be done by CLIA.

\subsection{Other diagnostics test}

A low-cost, CRISPR-based diagnostic platform "All-In-One-Dual CRISPR-Cas12a" (AIOD-CRISPR) was developed to detect infectious diseases, including the COVID-19 virus. The CRISPR technology is very handy and used in almost all organisms but its early applications were in plants. The AIOD-CRISPR test kit is very handy and can be used at home or in small clinics in order to reduce the further transmission of disease. The AIOD-CRISPR test has better sensitivity and specificity than PCR and can detect DNA and RNA of SARS-CoV-2 and HIV (Crop Biotech Update, 2020a).

\section{Treatment of COVID-19 infected persons}

COVID-19 is an emerging infectious disease and therefore continuous efforts are required to explore effective treatments for this emerging acute respiratory infection (Guan et al., 2020). The different treatment modalities have different efficacies at different stages of illness and in different manifestations of disease. Inhibition of virus would be expected to be the most effective early in infection. The National Institute of Health (NIH) published guidelines on prophylaxis use, testing and management of COVID-19 pateints. Currently, there are some antiviral drugs and vaccine available. The target of COVID-19 drugs has been illustrated in (Table.4). Immunomodulatory agents and anticoagulant may be useful to prevent disease progression and to prevent thromboembolic complications respectively.

\subsection{Respiratory support}

Oxygen therapy in patients with COVID-19 saves lives. Hospitalized patients (More than 75\%) with COVID-19 need supplemental oxygen therapy. The patients who are not responded to conventional oxygen therapy, heated high-flow nasal canula oxygen may be administered. For patients requiring invasive mechanical ventilation, lung-protective ventilation with low tidal volumes $(4-8 \mathrm{ml} / \mathrm{kg}$, predicted body weight) and plateau pressure less than $30 \mathrm{mg} \mathrm{Hg}$ is recommended (Alhazzani et al., 2019).

\subsection{Drugs used against COVID-19 infection}

\subsubsection{Remdesivir}

Remdesivir is a promising potential therapy for COVID-19 patients because of its broad-spectrum in vitro activity against SARS-CoV2. The remdesivir became the first drug that has received Food and Drug Administration (FDA) approval. Remdesivir (Veklury®) has been approved for the treatment of the hospitalized COVID-19 patients. As of October 22, 2020, remdesivir, an antiviral agent, was the only drug approved for treatment of COVID-19. The drug was developed by Gilead Sciences Inc. (USA). Previously remdesivir was tried against Ebola virus disease and it also showed promising effect in SARS and MERS (Ojha et al., 2020). The drug binds to the viral RNA-dependent RNA polymerase (RdRp) which leads to the inhibition of vital replication through premature termination of transcription of RNA.

Table 4: Targets of COVID-19 drugs

\begin{tabular}{|l|l|}
\hline 1. SARS-Cov-2 & 2. Human Immune System \\
\hline $\begin{array}{l}\text { Prevent the synthesis of } \\
\text { viral RNA (by acting on } \\
\text { genetic material of virus) }\end{array}$ & $\begin{array}{l}\text { Developing innate immune } \\
\text { response }\end{array}$ \\
\hline $\begin{array}{l}\text { Inhibiting the self assembly } \\
\text { of virus (by acting on } \\
\text { some structural protein) }\end{array}$ & $\begin{array}{l}\text { Controlling signal pathway of } \\
\text { human cell to lock virus } \\
\text { replication }\end{array}$ \\
\hline $\begin{array}{l}\text { Blocking the binding of } \\
\text { virus to human cell receptor }\end{array}$ & $\begin{array}{l}\text { Interferon to enhance } \\
\text { immune response }\end{array}$ \\
\hline $\begin{array}{l}\text { Inhibiting virus replication } \\
\text { (by acting on enzymes) }\end{array}$ & \\
\hline
\end{tabular}

\subsubsection{Favipiravir (Fabiflu $\left.{ }^{\circledR}\right)$}

Favipiravir, previously known as T-705, is a synthetic prodrug of a purine nucleotide, favipiravir ribofuranosyl-52 -triphosphate. This drug inhibits the RNA polymerase activity and halts the viral replication. Most of favipiravir's preclinical data are derived from its influenza and Ebola activity; however, the agent also demonstrated broad activity against other RNA viruses. Favipiravir was first drug used in Wuhan city at the epicenter of the pandemic against SARS-Cov-2. In June, 2020, the drug received DCGI (Drug Controller General of India) approval in India for mild and moderate COVID-19 infections (Search of: favipiravir. COVID19- list resultclinicaltrials.Gov.2020.https://clinicaltrials.gov/ct2/ results?cond $=$ Covid $19 \&$ term $=$ favipiravir $\&$ cntry $=\&$ state $=\&$ city $=\&$ dist Clinicaltrials.gov.). This drug was approved by Japan in 2014 for management of pandemic influenza infection. The mechanism of action of this drug is similar to remdesivir but administered orally. It can be given to patients who are symptomatic but not ill enough to be hospitalized (Agrawal et al., 2020). The recommended dosage of this drug in India is $1800 \mathrm{mg}$ orally twice daily followed by 800 $\mathrm{mg}$ twice daily upto maximum of 14 days.

\subsubsection{Chloroquine and hydroxychloroquine}

Chloroquine and hydroxychloroquine (hydroxyl derivative of chloroquine) have a long-standing history in the prevention and treatment of malaria and the treatment of chronic inflammatory diseases including systemic lupus erythematosus (SLE) and rheumatoid arthritis (RA) (Savarino et al., 2003). Both antimalarial drugs get huge attention because of its positive results from small studies. Chloroquine and hydroxychloroquine act by blocking the entry of virus into cells by inhibiting glycosylation of host receptors, proteolytic processing and endosomal acidification. These agents also have immunomodulatory effects through attenuation of cytokine production and inhibition of autophagy and lysosomal activity in host cells (Zhou et al., 2020; Devaux et al., 2020). Chloroquine inhibits SARS-CoV-2 in vitro with a half-maximal effective concentration $\left(\mathrm{EC}_{50}\right)$ in the low micromolar range. Hydroxychloroquine has lower $\mathrm{EC}_{50}$ value compared to chloroquine for SARS-CoV-2 in vitro after 24 hours of growth (Yao et al., 2020). However, chloroquine was successfully used to treat many COVID- 
19 patients in China and improved radiologic findings, enhanced viral clearance and reduced disease progression was observed (Gao et al., 2020). It has also been reported that addition of azithromycin to hydroxychloroquine in 6 patients resulted in numerically superior viral clearance $(6 / 6,100 \%)$ compared with hydroxychloroquine monotherapy (8/14, 57\%) (Gautret et al., 2020).

\subsubsection{Ivermectin}

It is an antiparasitic drug used to treat several tropical diseases (helminthiases, onchocerciasis and scabies) (Omura and Crump, 2014). Ivermectin is a FDA approved broad spectrum drug, which recently showed antiviral effect against SARS-Cov-2. The mechanism of action of this drug is by inhibiting the interactions between host HIV-1 integrase protein (IN) and the importin $\alpha / \beta 1$ heterodimer which is responsible for IN nuclear import (Wagstaff et al., 2011; Caly et al., 2020). As a result, $\alpha / \beta 1$ unable to bind to the viral protein and preventing it from entering the nucleus. In addition, ivermectin docking may also interfere with SARS-Cov-2 spike protein attachment to human cell membrane (Lehrer and Rheinstein, 2020).

\subsubsection{Lopinavir and Ritonavir}

Lopinavir and Ritonavir sold under the brand name of Kaletra, is an antiretroviral medication for the treatment and prevention of HIV/AIDS. These are used in combination with other antiretrovirals. Lopinavir and Ritonavir act by inhibiting the protease enzymes (a serine type protease, papain like proteases, the main protease or $\mathrm{M}^{\mathrm{pro}}$ ) which cleaves the polyproteins into non-structural proteins (nsps). These nsps are essential for synthesis of viral RNA (Liu and Wang, 2020). The combination of these drugs recommended for the treatment of corona patients in Italy.

\subsubsection{Oseltamivir (Tamiflu)}

In primary hospitals, Oseltamivir is a first-line antiviral drug. It was approved by the Food and Drug Admission (FDA) in 1999 as a neuraminidase inhibitor (Hayden et al., 1999). This drug has played an essential role in treating against influenza A and influenza B. Oseltamivir has also been used as anti-MERS-CoV and anti-SARSCoV 2 therapies in Korea and China, respectively (Al-Tawfiq et al., 2017; Wang et al., 2020). It has been found that the neuraminidase inhibitors may be useful to treat SARS-CoV because the active site of the Spike (S) 1 Protein of SARS is similar to that of neuraminidase (Zhang and Yap, 2004), but there was no expression of neuraminidase in SARS-CoV-2. From SARS-CoV in 2003 to MERS-CoV in 2012, and now the current SARS-CoV-2 pandemic, there is not plenty of evidence which suggest that oseltamivir is effective against coronavirus. There is a structure of some of drugs used in the treatment of COVID-19 pandemic (Figure 4).

\subsection{Plasma therapy}

The plasma of patients who have recovered from viral infections was reported for treatment of 1918 flu pandemic. The convalescent plasma therapy uses blood from people who have recovered from an illness to help others recover. The U.S. FDA authorized convalescent plasma therapy for people with COVID-19. The FDA allowed its use because there was no approved treatment available for COVID-19 at that time. Blood of the patients who have recovered from COVID-19 contain the antibodies against this virus and is processed to remove the blood cells, leaving behind plasma and antibodies. This can be given to people with COVID19 infection to boost their immunity to fight the virus.

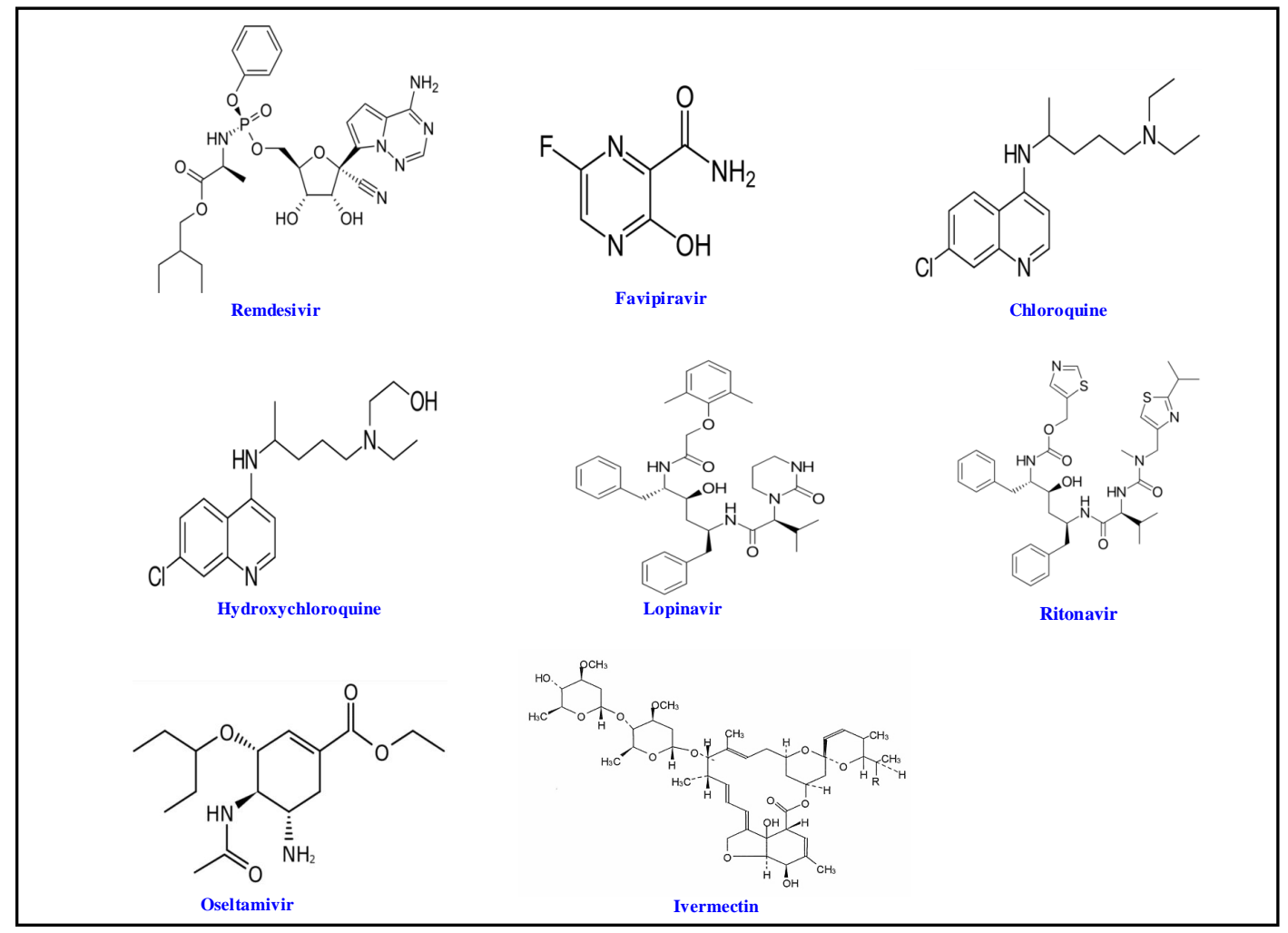

Figure 4: Structure of some of drugs combating COVID-19 virus infection. 


\section{Vaccines to prevent COVID-19 infection}

The most effective long-term strategy for prevention of future outbreaks of this virus would be the development of a vaccine providing protective immunity. Vaccines save millions of lives each year. Vaccines work by modulating the immune system of the host to recognize and fight off the pathogens (viruses and bacteria), they target. Later on, if vaccinated host is exposed to those pathogens, the body immediately tries to destroy them in order to prevent illness. Currently, there are 22 candidate vaccines in phase 3 clinical trials and 12 vaccines have been authorized across several countries (Table 5). Covid-19 pandemic continues to wreak havoc globally, with another wave expected in Europe during Christmas; at least 8 countries have begun or granted approval for vaccinating their people against the virus. The first full late-stage trial data of COVID-19 vaccine was released by US manufacturer Pfizer and German biotechnology company BioNTech on November 18, 2020. Britain, Canada and US Food and Drug Administration (FDA) approved the shot for emergency use on December, 2020. Moderna also released late-stage trial data which shows $94.1 \%$ efficacy for its vaccine.

Table 5: List of some vaccines to prevent COVID-19 infection

\begin{tabular}{|c|c|c|c|c|}
\hline S1.No. & Vaccine & Developed by & Dosage & Type of vaccine \\
\hline 1. & $\begin{array}{l}\text { Pfizer-BioNTech } \\
\text { (BNT162b2, Comirnaty) }\end{array}$ & $\begin{array}{l}\text { German company BioNTech in } \\
\text { cooperation with American } \\
\text { company Pfizer }\end{array}$ & Two doses & $\begin{array}{l}\text { RNA vaccine; nucleoside-modified } \\
\text { mRNA (modRNA) encoding a mutated } \\
\text { form of the spike protein of SARS-CoV-2, } \\
\text { encapsulated in lipid nanoparticles }\end{array}$ \\
\hline 2. & $\begin{array}{l}\text { AstraZeneca (code named } \\
\text { AZD1222 and marketed } \\
\text { as Covishield in India, by } \\
\text { Serum Institute of India ) }\end{array}$ & $\begin{array}{l}\text { Oxford University and } \\
\text { AstraZeneca (England) }\end{array}$ & Two doses & Modified chimpanzee adenovirus ChAdOx 1 \\
\hline 3. & Moderna s & $\begin{array}{l}\text { Made by Moderna of Cambridge, } \\
\text { Massachusetts, US National } \\
\text { Institute of Allergy and Infectious } \\
\text { Diseases }\end{array}$ & Two doses & Similar like Pfizer vaccine \\
\hline 4. & $\begin{array}{l}\text { Sputnik V } \\
\text { (Gam-COVID-Vac) }\end{array}$ & $\begin{array}{l}\text { Gamaleya Research Institute of } \\
\text { Epidemiology and Microbiology } \\
\text { (Russia) }\end{array}$ & Two doses & Adenovirus viral vector vaccine \\
\hline 5 . & $\begin{array}{l}\text { Johnson \& Johnson } \\
\text { (JNJ-78436735 or } \\
\text { Ad26.COV2.S) }\end{array}$ & \begin{tabular}{|l} 
Developed by the Janssen \\
Pharmaceutical Companies of \\
Johnson \& Johnson \\
(Headquarter-Belgium) \\
\end{tabular} & Single-dose & $\begin{array}{l}\text { Adenovirus-based vaccines } \\
\text { (uses double-stranded DNA.) }\end{array}$ \\
\hline 6. & Novavax (NVX-CoV2373) & $\begin{array}{l}\text { Novavax (Headquartered- } \\
\text { Gaithersburg, Maryland) } \\
\text { and Coalition for Epidemic } \\
\text { Preparedness Innovations } \\
\text { (CEPI) }\end{array}$ & Two doses & $\begin{array}{l}\text { Recombinant spike protein nanoparticle } \\
\text { with Matrix-M1 adjuvant }\end{array}$ \\
\hline 7. & $\begin{array}{l}\text { Covaxin (India's } \\
\text { indigenous COVID-19 } \\
\text { vaccine) }\end{array}$ & $\begin{array}{l}\text { Bharat Biotech (Hyderabad) in } \\
\text { collaboration with the Indian } \\
\text { Council of Medical Research } \\
\text { (ICMR) - National Institute of } \\
\text { Virology (NIV) (Pune). }\end{array}$ & Two doses & Viral vector vaccine \\
\hline 8. & EpiVacCorona & $\begin{array}{l}\text { Developed by the Vector } \\
\text { Institute (Russia) }\end{array}$ & & $\begin{array}{l}\text { Virus synthetic peptide antigens } \\
\text { (Peptide vaccine) }\end{array}$ \\
\hline 9 . & Convidicea (AD5-nCOV) & $\begin{array}{l}\text { Developed by CanSino } \\
\text { Biologics (China) }\end{array}$ & Single-dose & Adenovirus vector vaccine \\
\hline 10 . & $\begin{array}{l}\text { Sinopharm COVID-19 } \\
\text { vaccine (BBIBP-CorV) }\end{array}$ & $\begin{array}{l}\text { Developed by Sinopharm } \\
\text { (China) }\end{array}$ & & Inactivated whole virus vaccines \\
\hline
\end{tabular}

\section{Use of plants in COVID-19 management}

Vaccines are known to be the most cost-effective and efficacious method to decrease the disease burden of infectious disease. Thus, researchers strived towards developing an effective vaccine to combat the spread of COVID-19. Novel technologies are continuously being sought for improvement of product quality and reduction in production costs. The attenuated or inactivated pathogen or a disease causing organism or a suitable part of it has traditionally been used as vaccines. The sufficient quantity of this vaccine is then administered in to host to induce immunity. However, there are always chances for contamination with adventitious agents that can infect such vaccines.

An alternative and challenging possibility is the production of vaccine antigens in genetically modified plants. The vaccines from grown plants can be extracted and purified by appropriate methods. The benefits of such vaccines are that they could either be eaten or applied to mucosal surfaces. Plant biotechnology offers potential solutions to this pandemic. Humans relied on plants to cure diseases 
since ancient time. Many plants based active compounds are now part of modern pharmacotherapy. The ability of plants to synthesize a wide range of molecules is well known.

\section{Plant based vaccines}

Plant-based vaccines are considered as third-generation vaccines. Plant biotechnology harnesses the speed, flexibility and efficiency of plants to come up with vaccine candidates. The plant is a good candidate as biofactory because of its potential to make large quantities of high quality vaccine and antibodies (Crop Biotech, 2020b). Plant derived vaccines can be produced with less cost in high amounts. Carrier plants (corn or potato) are readily accepted by patients and antigens derived from them are stable and can be stored for a long time (WHO, 2015). Edible vaccines are recombinant vaccines in which selected antigens against a pathogen are introduced into a plant. This plant vaccine has to be taken orally to induce a protective immune response against pathogene (Aswathi et al., 2014). A variety of such proteins have been produced in plants and their promising tests results make them a very suitable candidate expression of other more clinically important recombinant proteins.

Hiatt and colleagues were first to made attempt to produce vaccines using plants since 1989. National Institute of Allergic and Infectious Diseases certified in 1998 that plant-based vaccines could induce sufficient immunogenicity in inoculated individuals. United States Department of Agriculture (USDA) approved world's first plantbased vaccine for poultry against Newcastle disease virus (NDV) after 8 years of research and development. It was shown to confer more than $90 \%$ protection in chicken, following the challenges faced with NDV (Vermij and Waltz, 2006). The single-chain fragment variable monoclonal antibody $(\mathrm{scFv} \mathrm{mAb})$ used in the production of a recombinant Hepatitis B virus vaccine is the other plant poduct licensed in Cuba (Naderi and Fakheri, 2015; Laere et al., 2016). Now, plant-made biopharmaceuticals have become a reality. Taliglucerase alfa, prescribed and marketed as replacement therapy for Gaucher's disease is a carrot based enzyme produced in a plant bioreactors (Mor, 2015). Zmapp (a plant-made monoclonal antibody cocktail) was administered to two patients in Guinea on a compassionate basis during the Ebola outbreak in 2014 (Tully et al., 2015).

\section{Plant biotechnology in combating COVID-19 infection}

The devastating projections of the impact of this pandemic in developing countries led to urgent development of low-cost production platforms for biologicals to fight COVID-19. The plantbased manufacturing of such recombinant molecules should be contemplated as one alternative.

Plant-based vaccines for COVID-19 can be developed:

- To induce active immunity by expressing the antigenic component of SARS-CoV-2.

- By expressing the antibody against the virus to provide passive protection.

The approach for plant-based vaccine production includes, cloning the vaccine candidate into a plant expression system, expression of the candidate gene in the plant and production of antigenic or protective protein. These plants can grow for multiple generations and will continuously produce the expressed recombinant protein
(Streatfield et al., 2001; Liew and Hair-Bejo, 2005; Phan and Conrad, 2016).

The use and cultivation of plant species as hosts for the production of valuable recombinant proteins, viz., antibodies, vaccines, hormones, enzymes is now named as molecular farming. Strategies for the production of recombinant proteins have been shown in (Figure 5).

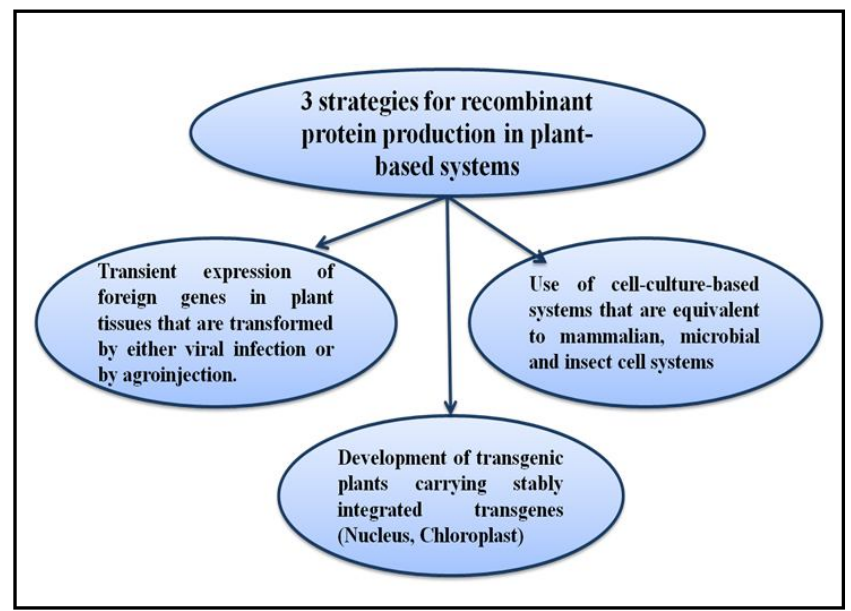

Figure 5: Strategies for the production of recombinant proteins.

\subsection{Transient expression}

Transient expression of recombinant proteins is an efficient system to produce proteins in different eukaryotic hosts. This is based on agro-infiltration or virus-based vectors to complement transgenic plants that have ability to express protein rapidly at high-level and considered convenient for the production of vaccines or monoclonal antibodies against infectious diseases (Figure 6). Plant transient expression system holds tremendous potential and an anti-Ebola antibody cocktail of three chimeric monoclonal antibodies was expressed in tobacco plants during Ebola outbreak in 2014 (Qiu et al., 2014).

COVID-19 pandemic has spread rapidly and created a huge demand for diagnostic reagents, vaccines, and therapeutic development. Plant transient expression system could be employed to produce recombinant proteins at high levels to meet the massive demand for production of viral antigens or antiviral proteins that could be used as research reagents, emergency vaccines (SARS-CoV-2 subunit and virus-like particle vaccines) or other biopharmaceuticals to fight against COVID-19 (Shanmugaraj et al., 2020a; Rosales-Mendoza, 2020). The plants based neutralizing monoclonal antibodies for passive immunotherapy against SARS-CoV-2 used could be produced with minimal investment (Shanmugaraj et al., 2020b).

Two companies have announced their programme for the development of plant-made vaccines and antibodies against SARSCoV-2 virus. After 21 days of having access to the SARS-CoV-2 virus $\mathrm{S}$ protein sequence, the production of VLPs (virus-like protein) in a transient expression system has been announced by the company Medicago Inc., therefore a rapid progress is expected for this development (Capell et al., 2020). The first step in development of a COVID-19 vaccine is the production of VLP. A VLP is a non- 
infectious version of a virus and Medicago used tobacco plant for the expression of this protein. However, in pandemic situations when demand is high, VLP alone cannot be used to quickly produce the vaccine for human use. For this purpose, adjuvants are used to enhance the immune response to viruses. It created a stronger and longer lasting immunity against infections than cannot be achieved by the vaccine alone. This technology is based on the insertion of a genetic sequence into a soil bacterium (Agrobacterium), which is taken up by plants. These plants begin to produce the protein which can be used as vaccine. If the virus begins to mutate, as is expected for COVID-19, they can just update the production using new plants (Crop Biotech Update, 020c).

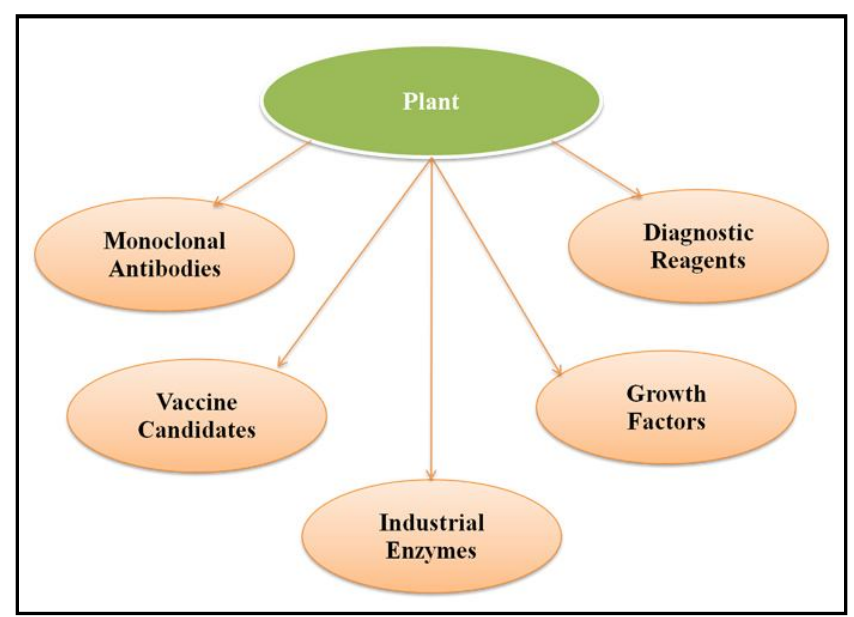

Figure 6: Transient expression system for the production of several recombinant proteins.

\subsection{Stable nuclear transformation}

It is the traditional approach of genetic manipulation in plants for production of recombinant protein. The transgene in the plant expression vector can be introduced into the in vitro grown plantlets either with Agrobacterium tumefaciens-mediated transformation or particle bombardment and stable transgenic lines can be developed. The stably integrated transgene into the plant genome can produce recombinant proteins in successive generations. The Arabidopsis thaliana and tobacco are model plants and very commonly used to develop stable transformants during the early stages of genetic transformation (Floss et al., 2008). The antigen expression in stable transgenic line could be used to develop oral vaccines which could subsequently reduce the cost associated with protein purification (Twyman et al., 2003; Yusibov and Rabindran, 2008).

\subsection{Stable chloroplast transformation}

Chloroplast expression aims on expressing the transgenes in chloroplast by the insertion of foreign gene into the chloroplast genome by homologous recombination. In recent years, the great progress has been made in chloroplast engineering. The chloroplast transformation has many advantages over nuclear transformation which includes higher protein production, polycistronic mRNA expression, lack of gene silencing and position effect and prevention of transmission of foreign DNA through pollen by uniparental plastid gene inheritance (maternal inheritance) in crop plants (Zhang et al., 2017).

\subsection{Cell suspension culture}

The cell suspension derived from undifferentiated callus can be cultivated in liquid medium in a plant bioreactors for large-scale production of desired protein under an aseptic environment. The first FDA-approved recombinant plant-produced pharmaceutical protein "Elelyso" and the first USDA-approved poultry vaccine were produced in carrot and tobacco cell suspension cultures, respectively. This established the importance and competitiveness of plant suspension culture in high-value protein production in the biopharmaceutical industry (Yusibov and Rabindran, 2008; Santos et al., 2016).

British American Tobacco (BAT) is developing a vaccine for COVID19 using tobacco plants. BAT and Kentucky BioProcessing (KBP) work with the U.S. Food and Drug Administration (FDA), U.S. Biomedical Advanced Research and Development Authority and United Kingdom's Department for Health and Social Care. A portion of COVID-19's genetic sequence has been cloned by KBP for development of a potential antigen. This antigen was inserted into tobacco plants for reproduction, purified after harvesting and used for pre-clinical testing. The tobacco plants are safer to use as it cannot host pathogens which cause human diseases. Moreover, the vaccine formulation in development remains stable at room temperature and easy to transport, unlike conventional vaccines which more often require refrigeration. Further, such vaccines have the potential to generate an effective immune response in a single dose (Crop Biotech Update, 2020d).

Further, development of epitope-based vaccines is need of hour in order to check the possibility of disease enhancement. iBio Inc. has a VLP vaccine in its pipeline (www.ibioinc.com/pipeline). Other companies with the potential to enter this race include Nomad (www.nomadbioscience.com/), Ventria (ventria.com/), Greenovation Biopharmaceuticals (www.greenovation.com/), Protalix (ww.protalix.com), and Kentucky Bioprocessing (www.kentuc kybioprocessing.com). Several academic institutions and universities and Institutes from several countries including the US, Germany, UK, South Africa, South Korea, Mexico, and Thailand are working in the molecular farming field and investing efforts in the COVID-19 topic.

\section{Herbal medicines against COVID-19 virus}

Researchers and people in the community find another way to cure and prevent COVID-19 disease by using herbal medicine (Table 6). Since the immunity of patient play an important role in COVID-19 infection, herbal medicine which has immunomodulatory effect could have the potential as a preventive measure and even a therapeutic agent for COVID-19 pateints (Sharma et al., 2009; Zhang and Liu, 2020). These days' herbal medicines are life saving drugs and research is being conducted on them because of their potential as antioxidant, anti-inflammatory and antiviral agent. During this period of global fretfulness, it is necessary to locate long lasting measures to avert the spread of this pandemic.

It has been reported that Yinqiao powder is the basic formulation used to treat the early infections of COVID-19. The pharmacological studies on Yinqiao powder revealed that it an expectorant effect which alleviates acute lung injury, improves lung function and relieves pulmonary fibrosis. It also reported to improve immune 
response to viruses and eases the adverse reactions of other drugs. The active ingredients in Yinqiao powder are rutin and hesperidin. Rutin binds to protease (3CLpro) of SARS-CoV-2 with more affinity than remdesivir, chloroquine, and hydroxychloroquine and also shown to inhibit SARS-CoV-2 by down-regulating interleukin-6. On the other hand, hesperidin has been found to have an inhibitory effect on human angiotensin-converting enzyme 2, GRP 78 , TMPRSS2 and AT1R receptors and, hence may be effective in the treatment of COVID-19. The other active ingredients present in Yinqiao powder are luteolin, eriodictyol, quercetin and naringenin. Though, there are no experimental data available to verify the specific role of Yinqiao powder against COVID 19 signaling pathways, possibly this drug acts via TNF signaling pathway, Toll-like receptor signaling pathway, T-cell receptor signaling pathway and MAPK signaling pathway (Lin et al., 2021). These signaling pathways are related to the occurrence and development of COVID 19 infections.

\section{Conclusion}

Plants have both technical and economic advantages over conventional expression system for the production of pharmaceutical and non-pharmaceutical products. The demand for recombinant proteins are increasing day-by-day and plant-derived vaccine or diagnostic reagent would be a feasible option. Use of plants as a transient expression system is a potential platform for recombinant proteins production for countering emerging deadly SARS-CoV-2. Plant biotechnology offer an alternate platform to produce and manufacture biologicals on a large scale within a time period of few weeks, compared to a longer time span of months required for cell culture-based approaches. The plant based vaccines have the potential but they have to overcome the challenges associated with such biologicals before clinical application to revolutionize the field of vaccinology.

Table 6: Herbal medicines used during COVID-19 pandemic

\begin{tabular}{|c|c|c|c|}
\hline S1. No. & Herbal medicine & Applications & References \\
\hline 1. & Curcuma longa (Asia) & $\begin{array}{l}\text { Antioxidant, anti-inflammatory, antimutagenic, } \\
\text { anticancer, antimicrobial } \\
\text { Block cytokine release specifically interleukin-1, } \\
\text { interleukin- } 6 \text {, proinflammatory cytokines and } \\
\text { TNF- } \alpha \text { and directed to consumed with milk }\end{array}$ & $\begin{array}{l}\text { Kocaadam and Sonlier, 2017; } \\
\text { Omara et al., } 2010\end{array}$ \\
\hline 2. & $\begin{array}{l}\text { Echinacea purpurea } \\
\text { (Europe and North America) }\end{array}$ & Antiviral & Hudson and Vimalanathan 2011 \\
\hline 3. & Cinchona & Antiviral, antimalarial, heal fever, immunomodulator & Abolghasemi et al., 2010 \\
\hline 4. & $\begin{array}{l}\text { Xanthorrhizol } \\
\text { (South east asian countries) }\end{array}$ & $\begin{array}{l}\text { Antioxidant, antiinflammatory, antimicrobial, } \\
\text { antihyperglycemic, anti hypertensive, antiplatelet, } \\
\text { nephroprotective, anticancer }\end{array}$ & $\begin{array}{l}\text { Maldonado et al., } 2017 \\
\text { Abolghasemi et al., } 2012 \\
\text { Vincent } \text { et al., } 2005\end{array}$ \\
\hline $\begin{array}{l}5 . \\
6 . \\
7 . \\
7\end{array}$ & $\begin{array}{l}\text { Zingiber officinale Roscoe } \\
\text { Syzygium aromaticum } \\
\text { Piper nigrum }\end{array}$ & $\begin{array}{l}\text { Provide support in the humoral and cell mediated } \\
\text { responses of COVID infected person }\end{array}$ & $\begin{array}{l}\text { Carrasco et al., 2009; } \\
\text { Kim and Lee, 2009; } \\
\text { Bui et al., } 2019\end{array}$ \\
\hline $\begin{array}{c}8 . \\
9 . \\
10 . \\
11 . \\
12 . \\
13 . \\
14 . \\
15 . \\
16 . \\
17 . \\
18 .\end{array}$ & $\begin{array}{l}\text { Indigofera tinctoria } \\
\text { Evolvulus alsinoides } \\
\text { Pergularia daemi } \\
\text { Gymnema sylvestre } \\
\text { Vitex trifolia } \\
\text { Clerodendrumineme } \\
\text { Abutilon indicum } \\
\text { Clitoria tematea } \\
\text { Leucas aspara } \\
\text { Allium sativum } \\
\text { Cassia alata }\end{array}$ & Anti-mice coronavirus activity (SARS- CoV) & Vimalanathan et al., 2009 \\
\hline
\end{tabular}

\section{Acknowledgments}

The author Alka Rani acknowledges the Senior Research fellowship from Indian Council of Medical Research, Govt. of India, New Delhi and Himachal Pradesh University, Summerhill, Shimla, India.

\section{Conflict of interest}

The authors declare that there are no conflicts of interest relevant to this article.

\section{References}

Abbasi, J. (2020). The Promise and Peril of Antibody Testing for COVID19. JAMA., 323(19):1881-1883. doi:10.1001/jama.2020. 6170.

Abolghasemi, E.; Moosa-Kazemi, S.H.; Davoudi, M.; Reisi,A. and Satvat, M.T. (2012). Comparative study of chloroquine and quinine on malaria rodents and their effects on the mouse testis. Asian Pac. J. Trop. Biomed., 2: 311-314.

Agrawal, U.; Raju, R. and Udwadia, Z.F. (2020). Favipiravir: Anew and emerging antiviral option in COVID-19. Med. J. Armed Forces India, 76: 370-376. 
Akbli, M.; El Rhaffari, L; Messaouri, H.; Rhallabi, N.; M'hand, R.A. and Mellouki, F. (2016). Ethnobotanical study of plants used in the treatment of cutaneous infections in urban areas of the region of Grand Casablanca - Morocco. IOSR J. Environ. Sci. Toxicol. Food Technol., 10:38-48. 10.9790/2402-1009013848.

Alhazzani, W.; Moller, M.H. and Arabi, Y.M. (2020). Surviving sepsis campaign: Guidelines on the management of critically ill adults with coronavirus disease 2019 (COVID-19). Intensive Care Med., 46:854-887. doi:10.1007/s00134-020-06022-5.

Al-Tawfiq, J.A.; Rabaan, A.A. and Hinedi, K. (2017). Influenza is more common than Middle East Respiratory Syndrome Coronavirus (MERS-CoV) among hospitalized adult Saudi patients. Travel Med. Infect. Dis., 20:56-60.

Amanat, F. and Krammer, F. (2020). SARS-CoV-2 vaccines: Status report. Immunity, 52(4):583-589. 10.1016/j.immuni.2020.03.007.

Aswathi, P.B.; Bhanja, S.K.; Yadav, A.S.; Rekha, V.; John, J.K.; Gopinath, D.; Sadanandan, G.V.; Shinde, A. and Jacob, A. (2014). Plant based edible vaccines against poultry diseases: A review. Adv. Animal and Veterinary Sci., 2:305-311. http://dx.doi.org/10.14737/journal.aavs/ 2014/2.5.305.311.

Bui,T.T.; Fan, Y.; Piao, C.H.; Van Nguyen,T.; Shin, D.U.; Jung, S.Y.; Hyeon, E.; Song, C.H.; Lee, S.Y.; Shin, H.S. and Chai, O.H. (2019). Piper nigrum extract improves OVA-induced nasal epithelial barrier dysfunction via activating Nrf2/HO-1 signaling. Cell. Immunol., 351.

Caly, L.; Druce, J.D.; Catton, M.G; Jans, D.A. and Wagstaff, K.M. (2020). The FDA-approved drug ivermectin inhibits the replication of SARSCoV-2 in vitro. Antivir. Res., 178:1047-1087. https://doi.org/ 10.1016/j.antiviral.2020.104787.

Capell, T.; Twyman, R.M.; Armario-Najera, V.; Ma, J.K.C.; Schillberg, S. and Christou, P. (2020). Potential applications of plant biotechnology against SARS-CoV-2. Trends Plant Sci., 25:635-643.

Carrasco, F.R.; Schmidt, G.; Romero, A.L.; Sartoretto, J.L.; Caparroz Assef, S.M.; Bersani Amado, C.A. and Cuman, R.K.N. (2009). Immunomodulatory activity of Zingiber officinale Roscoe, Salvia officinalis L. and Syzygium aromaticum L. essential oils: Evidence for humor and cell mediated responses. J. Pharma. Pharmacol., 61(7):961-967.

Castro, R.; Luz, P.M.; Wakimoto, M.D.; Veloso, V.G.; Grinsztejn, B. and Perazzo, H. (2020). COVID-19: a meta-analysis of diagnostic test accuracy of commercial assays registered in Brazil. Brazilian J. Infectious Dis. 24(2):180-187. doi:10.1016/j.bjid.2020.04.003

Chen, Y.; Guo, Y.; Pan, Y. and Zhao, Z.J. (2020). Structure analysis of the receptor binding of 2019-nCoV. Biochem. Biophys. Res. Commun., 525 135-140. 10.1016/j.bbrc.2020.02.071

Cheng, M.P.; Papenburg, J.; Desjardins, M.; Kanjilal, S.; Quach, C.; Libman, M.; Dittrich, S. and Yansouni, C.P. (2020). Diagnostic testing for severe acute respiratory syndrome-related Coronavirus-2. Ann. of Internal Med., M20-1301.10.7326/M20-1301.

Crop Biotech Update. (2020a). UConn researcher develops simple, lowcost CRISPR-based diagnostic test for COVID-19. http://www.isaaa.org/ $\mathrm{kc} /$ cropbiotechupdate/article/default.asp? ID $=18041$

Crop Biotech Update. (2020b). Native Australian plant paves way for vaccine development against COVID-19.

Crop Biotech Update. (2020c). Viable vaccine candidate for COVID-19 developed using proprietary plant-based technology.

Crop Biotech Update, (2020d). COVID-19 Vaccine development using new, fast-growing tobacco plant technology.

Devaux, C.A.; Rolain, J.M.; Colson, P. and Raoult, D. (2020). New insights on the antiviral effects of chloroquine against coronavirus: What to expect for COVID-19? Int. J. Antimicrob. Agents, 55(5):105938. doi:10.1016/j.ijantimicag.2020.105938.
Floss, D.M.; Sack, M.; Stadlmann, J.; Rademacher, T.; Scheller, J.; Stoger, E.; Fischer, R. and Conrad, U. (2008). Biochemical and functional characterization of anti-HIV antibody-ELP fusion proteins from transgenic plants. Plant Biotechnol. J., 6:379-391

Gao, J.; Tian, Z. and Yang, X. (2020). Breakthrough: Chloroquine phosphate has shown apparent efficacy in treatment of COVID-19 associated pneumonia in clinical studies. Biosci. Trends., 14:72-73. doi:10. 5582/bst.2020.01047.

Gates, B. (2020). Responding to Covid-19- a once-in-a-century pandemic? The New England J. Med., 382:1677-1679. https://doi.org/10.1056/ NEJMp2003762.

Gautret, P.; Lagier, J.C.; Parola, P. Hoang, V.T.; Meddeb, L.; Mailhe, M.; Doudier B.; Courjon, J.; Giordanengo , V.; Vieira, V.E.; Dupont, H.T.; Honoré, S.; Colson, P.; Chabrière ,E.; Scola , B.L.; Rolain, J.M.; Brouqui, P. and Raoult, D. (2020). Hydroxychloroquine and azithromycin as a treatment of COVID19: results of an open-label non-randomized clinical trial. Int. J. Antimicrob. Agents, 56(1):105949. doi:10.1016/j.ijantimicag.2020. 105949 .

Hayden F.G.; Treanor J.J. and Fritz R.S. (1999). Use of the oral neuraminidase inhibitor oseltamivir in experimental human influenza: Randomized controlled trials for prevention and treatment. JAMA., 282:12401246.

Huang, W.E.; Lim, B.; Hsu, C.C.; Xiong, D.; Wu, W.; Yu, Y.; Jia, H.; Wang, Y.; Zeng, Y.; Ji, M.; Chang, H.; Zhang, X.; Wang, H. and Cui, Z. (2020). RT-LAMP for rapid diagnosis of coronavirus SARS-CoV-2. Microb. Biotechnol., 13(4):950-996. doi:10.1111/1751-7915.13586.

Hudson, J. and Vimalanathan, S. (2011). Echinacea : A source of potent antivirals for respiratory virus infections. Pharmaceuticals, 4:10191031 .

Jiang, S.; Hillyer, C. and Du, L. (2020). Neutralizing antibodies against SARSCoV-2 and other human coronaviruses. Trends Immunol., 4:355-359.10.1016/j.it.2020.04.008.

Johani, S. and Hajeer, A.H. (2016). MERS-CoV diagnosis: An update. J. Infect. Public Health, 9:216-219.

Khan, S.; Siddique, R.; Shereen, M.A.; Ali,A.; Liu, J.; Bai, Q.; Bashir, N. and Xue, M. (2020). Emergence of a novel coronavirus, severe acute respiratory syndrome coronavirus 2: Biology and Therapeutic Options. Clin. Microbiol., 58:00187-20. https://doi.org/10.1128/JCM.00187-20.

Kim, S.H. and Lee, Y.C. (2009). Piperine inhibits eosinophil infiltration and airway hyperresponsiveness by suppressing $\mathrm{T}$ cell activity and Th2 cytokine production in the ovalbumin induced asthma model. J. Pharma. Pharmacol., 61(3):353-359.

Kocaadam, B. and Sanlier, N. (2017). Curcumin, an active component of turmeric (Curcuma longa), and its effects on health. Critic. Rev. Food Sci. Nutri., 57:2889-2895. doi: 10.1080/10408398.2015. 1077195.

WHO. (2020). Laboratory testing for coronavirus disease (COVID-19) in suspected human cases. Available from: https://www.who.int/ publications-detail/laboratory-testing-for-2019-novel-coronavirusin-suspected-human-cases-20200117.

Laere, E.; Ling, A.P.K.; Wong, Y.P.; Koh, R.Y.; Mohd Lila, M.A. and Hussein,S. (2016). Plant-based vaccines: production and challenges. J. Botany., pp:111. doi: $10.1155 / 2016 / 4928637$

Lee, J.; Chowell, G. and Jung, E. (2016). A dynamic compartmental model for the Middle East respiratory syndrome outbreak in the Republic of Korea: A retrospective analysis on control interventions and super spreading events. J. Theor. Biol., 408:118-26. https://doi.org/ 10.1016/j.jtbi.2016.08.009 
Lee,J.Y.; Kim, Y.J.; Chung, E.H.; Kim, D.W.; Jeong, I.; Kim, Y.; Yun, M.R.; Kim, S.S.; Kim, G. and Joh, J.S. (2017). The clinical and virological features of the first imported case causing MERS-CoV outbreak in South Korea, 2015. BMC Infectious Dis., 17:498. https://doi.org/10.1186/ s12879-017-2576-5.

Lehrer, S. and Rheinstein, P.H. (2020). Ivermectin docks to the SARS Cov-2 spike receptor-binding domain attached to ACE2. In vivo, 34:3023-3036.

Liew, P.S. and Hair-Bejo, M. (2015). Farming of plant-based veterinary vaccines and their applications for disease prevention in animals. Adv. Virol., pp:936-940. doi: 10.1155/2015/936940.

Lin, Haixiong, Xiaotong Wang, Minyi Liu, Minling Huang, Zhen Shen, Junjie Feng, Huijun Yang, Zige Li Junyan Gao and Xiaopeng Ye. (2021). Exploring the treatment of COVID 19 with Yinqiao powder based on network pharmacology. Phytother. Res., doi:10.1002/ptr.7012.

Liu, X. and Wang, X.J. (2020). Potential inhibitors against 2019-nCoV coronavirus $\mathrm{M}$ protease from clinically approved medicines. J. Genet. Genomics, 47:119-121.

Lu, R.; Zhao, X.; Li, J.; Niu, P.; Yang, B.; Wu, H.; Wang, W.; Song, H.; Huang, B.; Zhu, N. and Bi, Y. (2020). Genomic characterisation and epidemiology of 2019 novel coronavirus: Implications for virus origins and receptor binding. Lancet., 395:565-574. doi: https://doi.org/10.1016/S01406736(20)30251-8

Mackenzie, J.S. and Smith, D.W. (2020). COVID-19: A novel zoonotic disease caused by a coronavirus from China: What we know and what we don't. Microbiol. Australia, 41:45-50. doi: 10.1071/MA20013.

Maldonado, C.; Barnes, C.J. and Cornett, C. (2017). Phylogeny predicts the quantity of antimalarial alkaloids within the iconic yellow Cinchona bark (Rubiaceae; Cinchona calisaya). Front. Plant Sci., 8:1-16.

Mor, T.S. (2015). Molecular pharming's foot in the FDA's door: Protalix's trailblazing story. Biotechnol. Lett., 37:2147-2150.

Naderi, S. and Fakheri, B. (2015). Overview of plant-based vaccines. Res. J. Fish. Hydrobiol., 10: 275-89.

Ojha, P.K.; Kar, S.; Krishna, J.G.; Kunal Roy, K. and Leszczynski, J. (2020). Therapeutics for COVID-19: from computation to practiceswhere we are, where we are heading to. Mol. Divers, 25:625-659.

Omara, E.; Kam, A.; Alqahtania, A.; Li, K.; Razmovski-Naumovski, V.; Nammi, S.; Chan, K.; Roufogalis, B. and Li, G. (2010). Herbal medicines and nutraceuticals for diabetic vascular complications: mechanisms of action and bioactive phytochemicals. Curr. Pharm. Des., 16:37763807.

Omura, S. and Crump, A. (2014). Ivermectin: Panacea for resource-poor communities? Trends parasitol., 30:445-455.

Phan, H.T. and Conrad, U. (2016). Plant-based vaccine antigen production. Methods Mol. Biol., 13(49):35-47.

Piepenburg, O.; Williams, C.H.; Stemple, D.L. and Armes, N.A. (2006). DNA detection using recombination proteins. PLoS., 4:e204. https:// doi.org/10.1371/journal.pbio.0040204

Qiu, X.; Wong, G.; Audet, J.; Bello, A.; Fernando, L.; Alimonti, J.B.; FaustherBovendo, H.; Wei, H.; Aviles, J. and Hiatt, E. (2014). Reversion of advanced Ebola virus disease in nonhuman primates with ZMapp. Nature, 514(7520):47-53.

Rabi, F.; Al Zoubi, M.S.; Kasasbeh, G.A.; Salameh, D.M. and Al-Nasser, A.D. (2020). SARS-CoV-2CoV-2 and Coronavirus Disease 2019: What We Know So Far. Pathogens, 9:231.10.3390/pathogens9030231.

Rosales-Mendoza, S. (2020). Will plant-made biopharmaceuticals play a role in the fight against COVID-19? Expert Opin. Biol. Ther., 20 545-548.
Santos, R.B.; Abranches, R.; Fischer, R.; Sack, M. and Holland, T. (2016). Putting the spotlight back on plant suspension cultures. Front. Plant Sci., 7:297.

Savarino, A.; Boelaert, J.R.; Cassone, A.; Majori, G. and Cauda, R (2003). Effects of chloroquine on viral infections: an old drug against today's diseases. Lancet Infect. Dis., 3:722-727. doi:10.1016/ S1473-3099(03)00806-5.

Shanmugaraj, B.; Malla, A. and Phoolcharoen, W. (2020a). Emergence of novel coronavirus 2019-nCoV: Need for rapid vaccine and biologics development. Pathogens, 9:148.

Shanmugaraj, B.; Siriwattananon, K.; Wangkanont, K. and Phoolcharoen, W. (2020b). Perspectives on monoclonal antibody therapy as potential therapeutic intervention for Coronavirus disease-19 (COVID-19). Asian Pac. J. Allergy Immunol., 38:10-18.

Sharma, M.; Anderson, A.; Schoop, R. and Hudson, J.B. (2009). Induction of multiple pro-inflammatory cytokines.

Streatfield, S.J.; Jilka, J.M.; Hood, E.E.; Turner, D.D.; Bailey, M.R.; Mayor, J.M.; Woodard, S.L.; Beifuss, K.K.; Horn, M.E. and Delaney, D.E. (2001). Plantbased vaccines: Unique advantages. Vaccine., 19:2742-2748. doi:10.1016/S0264-410X(00)00512-0.

Tully, C.M.; Lambe, T. and Gilbert, S.C.(2015). Emergency Ebola response: a new approach to the rapid design and development of vaccines against emerging diseases. Lancet Infect. Dis., 15:356-359.

Twyman, R.M.; Stoger, E.; Schillberg, S.; Christou, P. and Fischer, R. (2003). Molecular farming in plants: Host systems and expression technology. Trends Biotechnol., 21:570-578.

Vashist, S.K. (2020). In vitro diagnostic assays for COVID-19: Recent advances and emerging trends. Diagnostics, 10:e202. doi:10.3390/ diagnostics 10040202

Vermij, P. and Waltz, E. (2006). USDA approves the first plant-based vaccine. Nature Biotechnol., 24:234.

Vimalanathan, S.; Ignacimuthu, S. and Hudson J.B. (2009). Medicinal plants of Tamil Nadu (Southern India) are a rich source of antiviral activities. Pharm. Biol., 47(5):422-429.

Vincent, M.J.; Bergeron, E. and Benjannet, S. (2005). Chloroquine is a potent inhibitor of SARS coronavirus infection and spread. Virol. J., 2:110

Wagstaff, K.M.; Rawlinson, S.M.; Hearps, A.C. and Jans, D.A. (2011). An AlphaScreen $(\mathrm{R})$-based assay for high-throughput screening for specific inhibitors of nuclear import. J. Biomol. Screen., 16:192200. https://doi.org/10.1177/1087057110390360.

Walls, A.C.; Park, Y.J.; Tortorici, M.A.; Wall, A.; McGuire, A.T. and Veesler, D. (2020). Structure, function, and antigenicity of the SARS-CoV-2 spike glycoprotein. Cell, 183:17-35.

Wang, D.; Hu, B.; Hu, C.; Zhu, F.; Liu, X. and Zhang, J. (2020). Clinical characteristics of 138 hospitalized patients with 2019 novel Coronavirus-infected pneumonia in Wuhan, China. JAMA., 323:1061-1069.

Guan,W.; Ni,Z; Hu, Y.; Liang, W.; Ou, C.; He, J.; Liu,L.; Shan, H.; Lei, C.; Hui, D.S.C.; Du, B.; Li, L.; Zeng, G.; Yuen, K.; Chen, R.; Tang, C.; Wang, T.; Chen, P.; Xiang, J.; Li, S.; Wang, J.; Liang, Z; Peng, Y; Wei, L.; Liu, Y; Hu, Y.; Peng, P. Wang, J.; Liu, J.; Chen, Z.; Li, G.; Zheng, Z; Qiu, S.; Luo, J.; Ye, C.; Zhu, S. and Zhong N. (2020). Clinical characteristics of 2019 novel coronavirus infection in China. medRxiv preprint. https://doi.org/10.1101/ 2020.02.06.20020974.

Weiss, S.R. and Leibowitz, J.L. (2011). Coronavirus pathogenesis. Adv. Virus Res., 81, Academic Press Inc. 85:164

WHO, (2015). Plant derived vaccines. 
Xu, X.; Chen, P.; Wang, J.; Feng, J.; Zhou, H.; Li, X.; Zhong, W. and Hao, P. (2020) Evolution of the novel coronavirus from the ongoing Wuhan out break and modeling of its spike protein for risk of human transmission. Science China Life Sciences, 63:457-460. 10.1007/s11427020-1637-5.

Yang, T.; Wang, Y.C.; Shen, C.F. and Cheng, C.M. (2020). Point-of-Care RNAbased diagnostic device for COVID-19. Diagnostics, 10:165. doi:10.3390/diagnostics10030165.

Yao, X.; Ye, F.; Zhang, M.; Cui , C.; Huang , B.; Niu, P.; Liu, X.; Zhao, L.; Dong, E.; Song, C.; Zhan, S.; Lu, R.; Li, H.; Tan, W. and Liu, D. (2020). In vitro antiviral activity and projection of optimized dosing design of hydroxychloroquine for the treatment of severe acute respiratory syndrome coronavirus 2 (SARS-CoV-2). Clin. Infect. dis., 71(15): 732-739. doi:10.1093/cid/ciaa237.

Yusibov, V. and Rabindran, S. (2008). Recent progress in the development of plant derived vaccines. Expert Rev. Vaccines, 7:1173-1183.
Zhang, B.; Shanmugaraj, B. and Daniell, H. (2017). Expression and functional evaluation of biopharmaceuticals made in plant chloroplasts. Curr. Opin. Chem. Biol., 38:17-23.

Zhang, L. and Liu, Y. (2020). Potential interventions for novel coronavirus in China: A systematic review. J. Med.1 Virol., 92: 479-490. doi: 10.1002/jmv.25707.

Zhang, X.W. and Yap, Y.L. (2004). The 3D structure analysis of SARS-CoV S1 protein reveals a link to influenza virus neuraminidase and implications for drug and antibody discovery. Theor. Chem., 681:137-141.

Zhou, D.; Dai , S.M. and Tong, Q. (2020). COVID-19: A recommendation to examine the effect of hydroxychloroquine in preventing infection and progression. J. Antimicrob. Chemothe., 75:1667-1670. doi: $10.1093 / \mathrm{jac} / \mathrm{dkaa} 114$. 